$\mathrm{A} \int_{\text {ars }} \mathrm{H}$

Article history :

Received : 20.03.2016

Revised : 02.04.2016

Accepted : 16.04.2016

Members of the Research Forum

Associated Authors:

${ }^{1}$ Department of Horticulture, College

of Agriculture, RAIPUR (C.G.) INDIA

Author for correspondence : SARITA SAHU

College of Agriculture and Research

Station, RAIGARH (C.G.) INDIA

Email : sarita.sahu2124@gmail.com
THEASIAN JOURNALOF HORTICULTURE

Volume 11 | Issue 1 | June, 2016 | 7-13

Visit us -www.researchjournal.co.in

\section{Sprouting, yield and economics of elephant foot yam (Amorphophallus paeoniifolius Dennst.) under the influence of different pre-planting treatments with organic and inorganic substances}

\section{SARITA SAHU AND VIJAY KUMAR ${ }^{1}$}

ABSTRACT : The aim of this study was to evaluate the sprouting, yield and economics of elephant foot yam under the influence of different pre-planting treatments using organic and inorganic substances. The pre-planting treatment of minisetts with thiourea at $400 \mathrm{ppm}$ resulted in maximum sprouting percentage $(97.22 \%)$. This treatment also recorded highest corm yield $\left(12.57 \mathrm{t} \mathrm{ha}^{-1}\right)$ and showed maximum increase in corm yield $(31.07 \%)$ over the control treatment. The economics over two years showed that among the different pre-planting treatments, the thiourea at $400 \mathrm{ppm}$ stood as the best treatment which gave maximum net return of Rs. 91851 with a B: C ratio of 2.71 followed by thiourea at $300 \mathrm{ppm}$ (net return Rs. 90651 and B: C ratio 2.69), thiourea at $200 \mathrm{ppm}$ (net return Rs. 88951 and $\mathrm{B}$ : C ratio 2.66) and $\mathrm{KNO}_{3}$ at $250 \mathrm{ppm}$ (net return Rs. 88021 and B: C ratio 2.66).

KEY WORDS : Corm, Minisetts, $\mathrm{KNO}_{3}$, Thiourea, $\mathrm{GA}_{3}$

HOW TO CITE THIS ARTICLE : Sahu, Sarita and Kumar, Vijay (2016). Sprouting, yield and economics of elephant foot yam (Amorphophallus paeoniifolius Dennst.) under the influence of different preplanting treatments with organic and inorganic substances. Asian J. Hort., 11(1) : 7-13, DOI : 10.15740/ HAS/TAJH/11.1/7-13. 